\title{
Membaca Perempuan Dalam Kumpulan Cerpen Perempuan yang Menunggu Karya Dorothea Rosa Herliany
}

\author{
Laura Andri Retno M \\ Jurusan Sastra Indonesia Fakultas Ilmu Budaya Universitas Diponegoro Semarang \\ Email: lauraandrirm@yahoo.co.id
}

\begin{abstract}
Positioning yourself as a woman by feeling all her existence and helplessness will make us able to read the text in a literary work of women. Literary works which written by female authors usually present messages and ideas contrary to the patriarchal system. If the reader simply places himself as a "reader" then he will not be able to capture the message and the idea. Instead they only concerned with the public's understanding and perception in general which is still dominated by patriarchal culture. Through the feminist's approach "read as a woman" in the essay collection Perempuan yang Menunggu (The Waiting Women) by Dorothea Rosa's, "women readers" will find concrete images of the condition of women in accordance with reality. They will read, interpret and understand the body of women as well as their own body and identity. Ultimately, women are able to free themselves from the frame constraints that limit their creativity and overhaul the existing patriarchal systems.
\end{abstract}

Keywords: female writer, female reader, body, feminist, patriarchy.

\section{Intisari}

Memposisikan diri sebagai perempuan dengan merasakan segala keberadaan dan ketakberdayaannya akan membuat kita berhasil membaca teks dalam sebuah karya sastra perempuan. Karya sastra yang ditulis oleh penulis perempuan biasanya menghadirkan pesan dan gagasan yang berlawanan dengan sistem patriarkat. Apabila pembaca hanya menempatkan diri sebagai "pembaca" maka ia tidak akan dapat menangkap pesan dan gagasan tersebut. Sebaliknya mereka hanya berkutat pada pemahaman serta persepsi masyarakat secara umum yang masih didominasi kultur patriarki. Melalui pendekatan feminis "membaca sebagai perempuan" dalam kumpulan cerpen Perempuan yang Menunggu karangan Dorothea Rosa, "pembaca perempuan" akan menemukan gambaran-gambaran konkret tentang kondisi perempuan sesuai dengan kenyataan yang ada. Mereka akan membaca, menginterpretasi serta memahami tubuh perempuan yang sekaligus tubuh dan identitasnya sendiri. Pada akhirnya, perempuan mampu membebaskan diri dari kungkungan frame yang membatasi kreativitas mereka dan merombak sistem patriarkat yang ada.

Kata kunci : penulis perempuan, pembaca perempuan, tubuh, feminis, patriarki.

\section{Pendahuluan}

Dewasa ini, perkembangan karya sastra di Indonesia menunjukkan gambaran yang menarik dan beragam. Perkembangan ini ditandai oleh beberapa hal, salah satunya 
dengan bermunculan karya-karya sastra hasil ciptaan penulis perempuan yang menghiasi rona kesusastraan Indonesia. Maraknya dunia sastra Indonesia bukan hanya karena kuantitas dan kualitas penciptaan yang berkaitan dengan hasil karya mereka, tetapi juga konsep estetika yang ditawarkan oleh masing-masing penulis perempuan tersebut. Ayu Utami, Fira Basuki, Djenar Maesa Ayu, Nukila Amal, Dorothea Rosa Herliany, Oka Rusmini merupakan contoh dari penulis perempuan Indonesia yang memiliki ciri serta gaya penulisan sendiri-sendiri. Meski konsep estetika serta genre sastra yang mereka hasilkan berbeda namun ada kesamaan dari masing-masing penulis tersebut, yaitu mereka tidak lagi menabukan penggambaran tindakan seks dengan segala organ-organnya. Hal ini dilakukan dalam rangka menyuarakan kebebasan dirinya sebagai seorang perempuan atau bahkan upaya pemberontakan atas stereotip gender yang sering disandangkan pada jenis kelaminnya. Interpretasi tentang tubuh dan darah perempuan merupakan sumber inspirasi serta semangat untuk menuliskan karya-karya mereka.

Karya sastra merupakan media yang digunakan oleh si penulis untuk menyampaikan gagasan-gagasannya. Karya sastra difungsikan sebagai jembatan untuk menghubungkan ide-ide kreatif penulis tersebut kepada pembaca. Tak heran jika akhirnya karya sastra ini berisi refleksi pandangan penulis terhadap berbagai macam masalah sebagai hasil dari pengamatan maupun pengalaman yang bersumber dari lingkungan mereka (Sugihastuti \& Saptiawan, 2007: 81-82). Dalam tulisan ini, peneliti hanya mengambil satu penulis perempuan untuk bahan analisa. Dorothea Rosa Herliany (selanjutnya disebut DRH) adalah penulis perempuan yang berani mengungkapkan realitas, pikiran, dan gagasan-gagasannya dalam karya sastra.

Menurut DRH, antara realitas, kreativitas, penciptaan, dan karya sastra menunjukkan satu jaringan mengikat yang khas. Realitas, sebagai sesuatu yang dihadapi oleh seorang kreator, adalah sumber dari karya kreatif. Kreativitas adalah "kemampuan unik" dari seorang kreator untuk menyusun "jaringan kerja penciptaan" yang dapat menghasilkan sebuah karya yang "personal". Ia memberi gerak dan wilayah bagi kreator untuk memberi jarak antara karya dan sesuatu yang ia tangkap (2003: viii). Sebagai penulis perempuan, DRH menyuguhkan gambaran kondisi perempuan berdasar atas kenyataan, meski selama ini kondisi yang berkaitan dengan isu-isu perempuan oleh sebagian masyarakat Indonesia masih merupakan hal yang tabu untuk dibahas ataupun diungkap. 
Dalam kumpulan cerpen Perempuan yang Menunggu (selanjutnya disebut PyM) bab pertama, sebagian besar tokoh yang dimunculkan oleh DRH adalah perempuan. Kehadiran tokoh-tokoh perempuan ini merupakan konstruksi imajinatif penulisnya. Agar keberadaan tokoh perempuan dan permasalahannya dalam cerpen bisa digali dengan semestinya dan tuntas maka diperlukan analisis yang tidak bias gender. Dengan kata lain, analisis permasalahan perempuan harus dilakukan melalui perspektif perempuan. Hellwig menyebut hal ini dengan "membaca sebagai seorang perempuan" (2003: 10). Pendapat ini sesuai dengan Showalter tentang perlunya mengambil titik pandang "woman as reader". Dengan demikian, membaca sebagai seorang perempuan dan atau perempuan sebagai pembaca akan membuat analisis tentang perempuan yang dikonstruksi pengarang dalam teks atau novel menjadi lebih tepat sasaran.

\section{Metode Penelitian}

Penelitian terhadap kumpulan cerpen $P y M$ berkaitan dengan pembacaan teks dari sudut pandang perempuan, maka penelitian teks yang seperti ini disebut sebagai penelitian yang berperspektif perempuan yang bertumpu pada permasalahan perempuan dan yang secara eksplisit menyatakan keberpihakannya kepada atau untuk perempuan. Penelitian yang berperspektif perempuan ini juga bersifat penelitian kualitatif yang menekankan pengalaman subjektif peneliti sebagai perempuan untuk memahami permasalahan perempuan yang muncul dalam teks yang dianalisis (Handayani dan Sugiarti, 2002: 77$78,85)$.

Sehubungan dengan hal di atas, maka teori yang paling tepat digunakan dalam penelitian ini adalah pendekatan feminis. Pengaplikasian teori tersebut memiliki manfaat penting berkaitan dengan upaya perempuan mendapatkan otoritas atas dirinya melalui perspektif sastra. Meski merupakan alat baru, pendekatan feminis dapat digunakan untuk mengkaji dan mendekati suatu teks. Dalam penelitian ini, penulis melakukan pembacaan interpretatif terhadap kumpulan cerpen $P y M$. Kemudian dilanjutkan dengan mengakumulasi data yang berupa teks-teks yang berhubungan dengan perspektif feminisme. Akhirnya, penulis melakukan analisis terhadap teks-teks data berdasarkan teori dan pendekatan feminis. Sehingga akan dihasilkan temuantemuan perspektif feminisme yang disajikan dalam laporan hasil analisis. 


\section{Hasil dan Pembahasan}

Pada umumnya, karya sastra yang menampilkan perempuan dalam karyanya bisa dikaji dari segi feministik. Asal ada tokoh perempuan dalam cerita, entah itu berperan sebagai tokoh utama atau tokoh bawahan, protagonis ataupun antagonis maka pendekatan feministik dapat digunakan untuk menganalisis karya tersebut. Namun demikian, pendekatan ini akan lebih mudah digunakan jika tokoh perempuan itu dikaitkan dengan tokoh laki-laki yang ada dalam karya sastra itu (Djajanegara, 2000: 51). Tidak dapat dipungkiri bahwa saat ini penelitian dengan menggunakan pisau analisis berupa kritik sastra feminis telah banyak diminati di Indonesia. Hal ini merepresentasikan adanya kesadaran bahwa fenomena keperempuanan dalam karya sastra harus diungkap dan dijelaskan kepada masyarakat.

Pendekatan feminis merupakan pendekatan yang menitikberatkan pada persoalan perempuan, yaitu melihat sesuatu dari sudut pandang perempuan. Sebab, apapun yang ada dalam kenyataan maupun dalam karya sastra selalu dilihat dari sudut laki-laki, sedang posisi perempuan hanya muncul ketika kaum laki-laki itu berinteraksi dengan kaum perempuan. Posisi perempuan selalu ditempatkan sebagai objek bukan sebagai subjek sehingga perempuan pun selalu diposisikan sebagai mahluk inferior dan laki-lakilah yang menjadi superiornya (Selden, 1993: 135-155). Mengingat kumpulan cerpen $P y M$ merupakan karya yang ditulis oleh seorang perempuan dan sebagian besar cerita bertokohkan perempuan serta selalu berkuat dengan persoalan-persoalan perempuan maka pendekatan ini sangat signifikan untuk menganalisis karya sastra tersebut.

\section{Sekilas tentang Dorothea Rosa Herliany dan Karyanya}

DRH adalah perempuan asal Magelang yang lahir 54 tahun silam, tepatnya tanggal 20 Oktober 1963. Anak keempat dari enam bersaudara ini mulai memilih menulis dan berkesenian sejak tahun 1980-an. Selain sebagai penyair yang sering membacakan puisi-puisinya di berbagai kota di dalam maupun luar negeri, ia aktif menulis baik novel maupun cerpen. Karya-karyanya termuat di berbagai media massa penting baik di dalam maupun luar negeri, seperti ; Horison, Kalam, Sinar Harapan, Kompas, Heat (Australia), The Age (Australia), Solidarity (Filipina), Archipel (Netherland), dan masih banyak lagi. 
Saat ini ia tinggal di sebuah desa di Magelang dan mendirikan Indonesia Tera, sebuah kelompok belajar kebudayaan dan masyarakat, sebuah lembaga swadaya nonprofit yang bekerja dalam lapangan penelitian, penerbitan, dokumentasi, dan pengembangan jaringan informasi untuk kebudayaan, pendidikan, dan kemasyarakatan. Buku-bukunya yang sudah diterbitkan dan menjadi konsumsi publik, antara lain : kumpulan puisi Nyanyian Gaduh, Matahari yang Mengalir, Kepompong Sunyi, Nikah Ilalang, Blencong, Kill The Radio Sebuah Radio Kumatikan, Perempuan yang Menunggu, dan lain sebagainya.

Objek material dalam penelitian ini adalah salah satu kumpulan cerpen karya DRH yang berjudul Perempuan yang Menunggu. Buku ini berisi 16 cerpen dan terbagi atas 2 bab. Bab pertama memiliki sub judul "Cermin (Pecah) Perempuan" dengan cerpen-cerpen, antara lain: "Sejenis Reptil”, "Mengalir”, “Kawin,lah!", "Bunga dalam Gelas", "Rumput-Rumput Meninggi”, "Sepotong Bulan Luka”, "Burung Lepas", "Dongeng Murti”, “Gerhana Bulan”, "Sang Bidak”. Bab kedua, memiliki sub judul “Topeng Rahwana”, dengan cerpen-cerpen antara lain: “Ke Jakarta Naik Delman”, "Ilalang Terbakar", "Cangklong dari Amerika", "Jagal”, “Topeng Rahwana”, "Sepotong Ikan Menari di Atas Mayat”. Berkaitan dengan pendekatan yang digunakan untuk menganalisis, penulis hanya akan mengambil bahan analisa bagian pertama (bab pertama) kumpulan cerpen yang ber sub judul "Cermin (Pecah) Perempuan" dengan 10 cerpen yang ada di dalamnya.

\section{DRH sebagai Perempuan yang Menulis Perempuan}

Berkaitan dengan proses menulis, DRH mengawalinya dengan kegiatan membaca terlebih dahulu. Membaca di sini berarti membaca "tanda" dari tubuh perempuan (signified) serta mengkorelasikan "tanda" itu dengan signifier nya. Ia memposisikan diri sebagai pembaca untuk memahami tanda-tanda yang ada dalam tubuhnya sendiri. Karena pada praktiknya, orang tidak akan dapat menulis tanpa melewati proses membaca. Kemudian pemahaman dan pengalaman itu ia tuangkan dalam teks berdasarkan atas kesadarannya sebagai perempuan. Apa yang menjadi persepsi penulis laki-laki ketika mereka berbicara tentang tubuh, pengalaman serta seksualitas perempuan akan berbeda hasilnya dibanding ketika penulis perempuan berbicara tentang tubuh serta pengalaman batin mereka sendiri. Meski penulis laki-laki merasa sangat mampu berbicara tentang hal tersebut tetapi kenyataan yang ada menunjukkan 
bahwa persepsi-persepsi mereka adalah bias. Sebab mereka bukanlah perempuan, penulis laki-laki menulis berdasarkan atas kesadarannya sebagai laki-laki. Tingkat pemahaman mereka terhadap pengalaman dan kondisi batin perempuan berbeda dibanding dengan perempuan yang menulis sendiri pengalaman dan kondisi jiwa perempuan itu sendiri.

Selama ini perempuan hanya disuguhi karya-karya berisi pengalaman mereka yang ditulis oleh penulis laki-laki. Teks yang bersifat subjektif yang dilihat dari pemahaman dan sudut pandang laki-laki saja. Perempuan dipaksa untuk membaca dan memahami tanda-tanda dalam tubuh mereka sendiri dengan cara seperti yang ditempuh oleh laki-laki dalam usaha memahami tubuh mereka. Tentu saja dominasi kultur patriarki masih melekat di dalamnya. Dalam kultur patriarki, laki-laki dinilai mempunyai kemampuan untuk berpikir. Mereka adalah manusia yang cerdas yang mempunyai kemampuan menggunakan otaknya. Sementara perempuan adalah sebaliknya. Ia dianggap sebagai mahluk yang bodoh dan tidak berotak. Keyakinan ini mengakar begitu kuat sehingga seringkali diterima mentah-mentah tanpa ada usaha lebih lanjut untuk mempertanyakannya secara kritis. Sehingga, apapun tema cerita yang dihasilkan dalam teks-teks yang diciptakan oleh penulis laki-laki, perempuan selalu mendapat posisi kedua setelah mereka. Perempuan hanya ditempatkan sebagai objek oleh laki-laki, bukan subjek yang bisa menuliskan pengalaman dan perasaannya sesuai dengan cara dan bahasa mereka sendiri.

Melalui kumpulan cerpen $P y M$, DRH menghadirkan pesan dan gagasan yang berlawanan dengan sistem patriarkat yang masih berkembang di Indonesia hingga sekarang. Sebagai penulis perempuan, ia mencoba membaca, menginterpretasi serta memahami tubuh perempuan yang sekaligus tubuh dan identitasnya sendiri. Ia menyuguhkan gambaran-gambaran konkret tentang kondisi perempuan sesuai dengan kenyataan yang ada.

Dalam proses kreatifnya, DRH menggunakan gaya bahasa serta ungkapan lebih halus dibanding penulis-penulis perempuan lain. Penulis cenderung menggunakan latar budaya Jawa dalam setiap penceritaan yang dihadirkan. Meski budaya Jawa menjadi ciri dalam karya-karyanya tetapi sedikit banyak ia mampu menggeser sistem patriarki yang masih melekat di dalamnya. Hal ini berkaitan dengan cara pandang atau persepsi masyarakat terhadap perempuan serta konsep-konsep pikiran yang membentuk perilaku perempuan itu sendiri. 


\section{Materialistik, Tubuh dan Seks}

“Apa bedanya? Kamu jelas sudah melenceng. Melenceng dari pikiran seorang istri yang sudah jadi ibu dua nyawa yang manis-manis itu. Yang kamu buru apa? Coba aku tanya. Wajah tampan? Harta? Atau kesenangan biologis? Lalu apa suamimu, Mas Dirun, menurutmu tak bisa memenuhi semuanya? Atau....ah, kalau menuruti hawa nafsu, nggak akan cukup wis...." (“Sejenis Reptil”, 2003: 4).

Kutipan cerpen di atas, menunjukkan perempuan yang selama ini dikenal oleh masyarakat memiliki karakter dasar materialistik, mengutamakan tampilan fisik dan orientasi pada kepuasan biologis atau seksual. Anggapan ini dimunculkan dan dibenarkan oleh perspektif patriarki. Perempuan diposisikan sangat lemah dan hanya berkutat pada zona yang ada pada dirinya sediri. Masyarakat beranggapan bahwa materi/kebendaan, tampilan fisik atau kemolekan tubuh serta seks adalah bagian yang tidak pernah bisa dilepaskan ketika mereka menilai seorang perempuan.

Berdasar atas kesadaran dan pengalamannya sebagai perempuan, penulis memiliki cara pandang yang berbeda dan berlawanan dengan perspektif patriarki di atas. Bagi penulis, orientasi pada materi, tubuh dan seks hanyalah sekedar penilaian yang dimunculkan oleh ideologi patriarki. Ideologi ini pula yang sering disebut sebagai penyebab ketidakadilan gender karena ia telah banyak melahirkan berbagai bentuk penindasan terhadap perempuan.

"Suami yang bahagia mungkin yang menemukan istrinya selalu setia menunggu di rumah, menyediakan teh atau kopi tiap suaminya butuh kehangatan? Atau, ia selalu tampak anggun di depan suaminya?" ......("Bunga dalam Gelas", 2003:25)

Sepenggal kutipan ini membuktikan bahwa patriarki menempatkan perempuan sebagai laki-laki yang inferior. Pemahaman ini digunakan baik secara langsung atau tidak langsung dalam kehidupan sipil dan rumah tangga untuk membatasi ruang gerak perempuan. Dalam perspektif patriarki, laki-laki menduduki posisi yang lebih tinggi dalam hierarki dikotomis, ia mempunyai privilese untuk mempekerjakan perempuan. Sebagai akibatnya, perempuan harus menerima saja posisinya sebagai pihak yang dipekerjakan. 


\section{Perkawinan}

Alasan itulah yang memojokkanku pada kenyataan yang sekarang kuhadapi. Umurku memasuki tahun 32. Sesungguhnya makin terasa pahit jika aku merasa orang-orang mulai mengolokku sebagai perawan tua. Bahkan ada yang berbisikbisik mengejekku sebagai tidak laku, tidak ada yang tertarik padaku. Siapa bilang begitu? Sudah berapa pria mencoba mematahkan pertahananku. Mereka juga bukan tergolong pria di bawah standar idaman orang tua. Pendidikan, pekerjaan, dan bahkan dari keluarga apa mereka berasal..... ("Kawin,lah!", 2003: 20-21).

Kutipan cerpen di atas menunjukkan internalisasi peran gender yang diperuntukkan bagi perempuan. Hal ini mewakili nilai-nilai patriarki tentang pentingnya perkawinan bagi seorang perempuan. Merupakan sebuah kewajiban bagi mereka untuk menikah dan membina rumah tangga. Masyarakat menganggap tidak layak apabila perempuan yang cukup usia tidak menikah apalagi jika usia mereka sudah tua. Perkawinan dalam lingkup patriarki selalu menempatkan perempuan dalam ranah domestik atau lebih tepatnya pada posisi pelayan. Setelah kawin/menikah, perempuan akan menjadi pelayan biologis bagi suaminya serta pelayan rumah tangga bagi anak dan keluarganya. Disadari atau tidak, dengan dalih "mengabdi" atau "kewajiban" semua beban itu sudah menjadi tugas bagi perempuan. Dalam hal ini, perempuan tidak mempunyai kuasa atas diri dan tubuhnya sendiri.

Perspektif patriarki tersebut dibantah oleh DRH. melalui kutipan dari cerpen yang sama di bawah ini:

Ya, kakakku benar. Aku harus mengambil sebuah keputusan. Tetapi? Ternyata tidak mudah memutuskan kawin, sebuah sikap yang melunakkan pertahananku hampir 10 tahun untuk tidak mengambil keputusan itu untuk dirampok orang. Memilih satu dari tiga pilihan yang sama-sama beratnya, membutuhkan waktu lama. Mungkin di usia 35 tahun nanti, aku baru bisa mengakhiri masa lajangku (“Kawin,lah!”, 2003: 20-21).

Ketika ayah berkata bahwa saat aku kawin nanti, artinya ia akan menyerahkan segalanya untuk takdimilikinya lagi, aku tidak percaya. Perkawinan bagiku hanya prosesi kesepakatan dua orang asing untuk membangun hidup serba baru. Bukan berarti kemudian seluruh atau sebagian hidupnya yang lama lantas hilang. Barangkali kalaupun terjadi sesuatu, hanya perubahan menjaadi sesuatu yang lebih segar (“Kawin,lah!”, 20003: 17).

Melalui bait-bait di atas, DRH ingin menunjukkan bahwa ikatan perkawinan bukan lagi tujuan utama bagi perempuan. Kawin/menikah juga bukan sebagai kewajiban melainkan pilihan yang apabila perempuan tidak merasa perlu, ia berhak menolak untuk melakukannya. Tentu saja tanpa beban moral yang dimunculkan oleh masyarakat 
(melalui anggapan "perempuan tua") bagi mereka. Selain itu kematangan usia dalam perkawinan tidak bisa diukur berdasarkan angka tahun dan kondisi biologis semata tetapi lebih mengarah pada kesiapan psikologis dan materi bagi si perempuan. Ada upaya penggeseran sistem patriarki yang pelan-pelan dilakukan oleh DRH. Bagi DRH, perempuan juga memiliki otoritas/kuasa atas tubuh, jiwa serta seksualitasnya sendiri.

\section{Kesetiaan $><$ Penyerahan Diri Total}

Ia selalu berkata bahwa seorang istri seperti kertas dengan pena di atasnya. Ia harus kosong dan siap jika setiap saat suaminya ingin menuliskan sesuatu di atasnya ("Bunga dalam Gelas", 2003:22).

Bagi Dirjo, kejujuran adalah penelanjangan yang semata-mata agar ia mendapatkan sebuah kertas putih untuk ditulisi kemudian. Ia, sebagai suami, merasa bahwa laki-laki adalah penulis cerita. Dan ia juga merasa berhak membuat sandiwara di panggung lainnya ("Mengalir", 2003: 15).

Dalam kutipan kedua cerpen tersebut tampak pandangan patriarki tentang bagaimana sikap istri seharusnya. Penggunaan istilah "kosong" dan "kertas putih" pada kutipan di atas menyimbolkan karakter perempuan yang harusnya pasrah, menyerah, patuh dan setia terhadap kehendak suami. Laki-laki berlaku sebagai pusat segala sikap dan perilaku perempuan sekaligus pengendalinya. Ia diumpamakan sebagai "pena" dan "penulis cerita". Hal ini menunjukkan bahwa laki-laki dapat melakukan apapun, menuliskan apapun yang ia mau terhadap hidup perempuan. Karena perempuan hanya boleh (sekedar) menerima nasib yang dibuat suami terhadap mereka. Laki-laki adalah Tuhan dalam keluarganya.

Penanaman nilai patriarki tentang kesetiaan dan kepasrahan perempuan ini juga dibantah oleh DRH, melalui kutipan di bawah ini:

Lalu kuingat serentet narasi tentang kesetiaan dari setiap orang yang kutemui, dan akhirnya kusimpulkan betapa kesetiaan adalah sikap dengan batas-batas semu. Boleh jadi juga hanya berupa segumpal sugesti moral, atau pengingkaranpengingkaran terhadap suatu sikap (2003: 22-23).

Dengan mewakili jiwa dan tubuh perempuan, DRH menolak anggapan patriarki tentang makna kesetiaan yang disamaartikan dengan penyerahan diri total. Justru anggapan inilah yang akhirnya mengaburkan makna dari kesetiaan itu sendiri. Kesetiaan bagi perempuan adalah sikap yang dilandasi oleh kesadaran akan hak serta kewajibannya sebagai perempuan. Menjaga kesetiaan dalam perkawinan bukanlah mutlak tanggung 
jawab istri semata tetapi juga kewajiban suami untuk tidak melakukan pengingkaran terhadap pasangannya.

\section{Membaca Perempuan dalam Perempuan Yang Menunggu}

Dalam proses membaca $P y M$, pembaca harus bisa menempatkan diri sebagai pembaca aktif. Dengan kata lain, seorang pembaca tidak selalu bersikap pasif, ia kadang harus aktif berpartisipasi di dalam memproduksi makna dari teks. Seorang pembaca harus menggunakan imajinasinya supaya bisa memahami makna teks yang sedang dibaca. Meski bukan berarti bahwa makna teks merupakan rekayasa konstruktif dari pembaca itu sendiri. Menurut Indrarti, ketika perempuan mulai masuk dalam ranah literacy, posisi membaca atau posisi pembaca perempuan, akan sangat problematik apabila ia mempertimbangkan faktor sosial-budaya, terutama yang berkaitan dengan ideologi gender. Faktor ideologi gender inilah yang berperan sangat signifikan untuk menentukan perbedaan dan kesamaan frame dalam proses pemaknaan (2009: 105). Hal ini disebut juga dengan istilah posisi pembaca perempuan (the position of a woman reader). Yang dimaksud dengan "pembaca perempuan" (woman reader) di sini termasuk pula "penulis perempuan" (woman writer) karena proses menulis selalu diawali dengan proses membaca.

Culler melalui Sofia (2002: 20-21), menawarkan konsep reading as a woman sebagai bentuk kritik sastra feminis. Konsep ini dilakukan melalui sebuah pendekatan yang berusaha membuat pembaca menjadi kritis hingga menghasilkan penilaian terhadap makna teks, yaitu dengan menganalisis ideologi kekuasaan laki-laki yang patriarkal yang diasumsikan terdapat dalam penulisan dan pembacaan sastra. Selanjutnya, dalam reding as a woman seorang penganalisis menghadapi suatu karya dengan berpijak pada kesadaran bahwa ada jenis kelamin yang berbeda yang mempengaruhi dan banyak berhubungan dengan budaya, sastra, dan kehidupan. Membaca sebagai perempuan berarti membaca dengan kesadaran membongkar praduga dan ideologi kekuasaan laki-laki yang andosentris dan patriarkal.

\section{Tentang Pelacuran}

Aku mendesaknya untuk berkata lebih rinci dan detail tentang hal yang menggiringnya untuk berkata begitu padaku. "kemarin aku bertemu Ida," ujarnya, "Ia berusaha mengelak dan sembunyi ketika melihatku, dan aku membiarkannya karena memahami keadaannya." 


\begin{abstract}
Aku benar-benar terkejut.
"Aku tidak menduga bertemu Ida. Coba kalau saja temanku dari Jakarta tidak memintaku mengantar ke tempat hiburan yang paling bersih di kota ini. Dan kau tahu? Aku tak pernah menduga bahwa Labaida akan berada di sana. Menurut sesorang yang bisa dipercayadi tempat hiburan itu, ia di sana sejak setengah tahun lalu," kata Budi ("Rumput-rumput Meninggi", 2003: 40).
\end{abstract}

Kutipan cerita di atas menunjuk pada reaksi perempuan yang karena suatu peristiwa tertentu, lantas membuat ia menentukan pilihan untuk tinggal dan bekerja di sebuah tempat hiburan atau melacurkan diri. Cerita ini sangat sederhana, tetapi jika dilihat dari sisi perempuan, ternyata metafor yang digunakan oleh penulisnya memunculkan interpretasi yang beragam. Pertama, pekerjaan melacurkan diri jangan hanya dilihat dari sisi negatif saja. Karena apabila perempuan mengambil posisi ini atas dasar materi untuk menafkahi dan menyelamatkan keluarganya, masyarakatpun harus bisa memahami hal tersebut. Terlebih jika laki-laki atau suaminya tidak bekerja dan hanya mengandalkan istri sebagai tulang punggung keluarga. Dalam hal ini perempuan berlaku sebagai "penguasa" atas keluarganya. Ia memiliki otoritas penuh karena tanggung jawab yang disandangnya.

Kedua, keinginan menjadi pelacur bukan didasari oleh kebutuhan akan materi/uang. Tetapi lebih mengarah pada sikap laki-laki yang telah menyakitinya sehingga rasa sakit dan kebencian itu ia lampiaskan dengan menjadi pelacur. Melalui profesi ini, perempuan yang menjadi pelacur bisa menumpahkan dendamnya dan membuat banyak laki-laki lain balas tersakiti oleh diri perempuan itu. Dalam posisi ini, perempuan bisa berlaku bukan sebagai objek yang "menerima segala perlakuan" tetapi ia bertindak sebagai subjek yang "mengendalikan". Dengan representasi seksualitas yang dihadirkan melalui tubuhnya, perempuan berusaha melepaskan diri dari wacana korban. Ini adalah bukti bahwa perempuan tidak selalu merupakan korban/objek karena perempuan memiliki kesadaran.

Ketiga, jika pekerjaan menjadi pelacur bukan pekerjaan yang dilakukan berdasarkan keinginannya melainkan paksaan atas kekuasaan orang lain, apakah masyarakat juga masih akan memandang perempuan tersebut dari sisi negatif pekerjaannya saja? Tentunya dengan setumpuk sanksi sosial yang dimunculkan dan sangat membebani peran perempuan. Dalam hal ini, masyarakat hanya melihat dari perwujudan perempuan itu sebagai pelacur tanpa mau melihat latar belakang yang mendasari mengapa ia memilih atau dipaksa memilih profesi tersebut. 


\section{Tentang perselingkuhan}

"Dengarlah, Anak-anakku! Ketahuilah bahwa selama ini Ibu telah berkali-kali bercinta di luar rumah. Ingat! Bercinta. Bukan bersenang-senang. Artinya, Ibu merasa tak mendapatkan cinta di rumah ini. Lalu Ibu menemukan di luar pintu rumah. Apa salahnya Ibu meraih itu? Kemudian, Ibu merasa bahwa selama ini Ibu menanggung beban yang tak bisa Ibu pungkiri. Kalian semakin bodoh dan lugu. Tak mampu berbuat dan berpikir di sebuah ruangan yang dikitari jaring berduri ini. Maka Ibu makin merasa betapa sia-sia Ibu berharap menjadi perubahan. Kalian paham?" ("Mengalir", 2003: 13).

Perselingkuhan yang menjadi inti dari cerita tersebut, jika kita lihat berdasarkan perspektif perempuan akan beda hasilnya dibandingkan apabila kita melihat dengan menggunakan perspektif patriarki. Dalam perspektif patriarki, perempuan yang melakukan perselingkuhan akan mendapat hukuman berupa sanksi sosial sesuai dengan aturan-aturan yang ada dalam masyarakat. Sementara itu melalui perspektif perempuan, muncul interpretasi yang berbeda. Perselingkuhan dapat muncul karena didasari atas adanya dorongan kebutuhan seks. Kebutuhan seks merupakan kebutuhan yang diinginkan perempuan sebagai manusia normal yang memiliki hasrat biologis sepertinya halnya laki-laki. Jika hal itu tidak dipenuhi oleh suaminya, perempuan tidak boleh membiarkan dirinya memperoleh pemenuhan kebutuhan dari laki-laki lain. Hal ini disebabkan karena norma patriarki tidak memberikan ruang bagi perempuan untuk memperoleh pemenuhan kebutuhan seksualitasnya di luar lembaga perkawinan.

Apabila perempuan tetap membiarkan dirinya menikmati hubungan seks dengan laki-laki lain (seperti yang dilakukan oleh tokoh "Ibu") maka dapat direpresentasi bahwa perempuan juga mempunyai kebutuhan seks yang sama mendesaknya seperti kebutuhan seks yang dialami laki-laki. Kebutuhan seks oleh tubuh yang merupakan bagian dari konstruksi diri perempuan ini juga menuntut akan adanya sebuah pemenuhan yang bersifat memuaskan. Keputusan "Ibu" melakukan perselingkuhan menunjukkan bahwa ia menjalani tubuhnya sebagai "subjek". Kebutuhan yang dirasakan oleh tubuhnya tidak semata-mata bersifat ragawi, melainkan kebutuhan ragawi yang erat berhubungan dengan keseimbangan mental. Perselingkuhan mengibaratkan adanya kehampaan, kesunyian, atau kebisuan yang berpotensi untuk melakukan pemenuhan atas kebutuhan tersebut. 


\section{Simpulan}

Berdasarkan pembahasan di atas terlihat bahwa karya sastra merupakan hasil refleksi pengarang terhadap lingkungan sekitarnya melalui proses pengamatan maupun pengalaman mereka. Sebagai penulis perempuan, lewat kumpulan cerpen Perempuan yang Menunggu, Dorothea Rosa Herliany mencoba membaca, menginterpretasi serta memahami tubuh perempuan yang sekaligus tubuh dan identitasnya sendiri. Ia mencoba menyuguhkan gambaran-gambaran konkret tentang kondisi perempuan sesuai dengan kenyataan yang ada dan menghadirkan pesan dan gagasan yang berlawanan dengan sistem patriarkat yang masih berkembang di Indonesia hingga sekarang. Untuk memahami pesan dan gagasan dari penulis, pembaca harus mampu menempatkan dirinya sebagai perempuan. Seorang pembaca perempuan bisa berhasil membaca teks sebagai perempuan apabila ia mampu membangun identitas diri dari pengalamannya sendiri. Dengan demikian, para pembaca akan mampu menghapus hirarki gender yang memarjinalkan mereka.

\section{Daftar Pustaka}

Culler, Jonthan. 1983. On Deconstruction: Theory and Criticism after Structuralism. London and Henly: Routledge and Kegan Paul.

Djajanegara, Soenarjati. 2000. Kritik Sastra Feminis: Sebuah Pengantar. Jakarta: Gramedia.

Handayani, Trisakti dan Sugiarti. 2002. Konsep dan Teknik Penelitian Gender. Malang: UMM Press.

Hellwig, Tineke. 2003. In the Shadow of Change: Citra Perempuan dalam Sastra Indonesia. Terjemahan Rika Iffati Farikha. Depok: Desantara.

Hendrarti, IM. 2009. "Bila Seorang Perempuan Membaca Perempuan”. Kajian Sastra: Jurnal Bidang Kebahasaan dan Kesusastraan (hal 103-117).

Herliany, Dorothea Rosa. 2003. Perempuan Yang Menunggu. Magelang: IndonesiaTera.

Priyatna, Aquarini. 2006. Kajian Budaya Feminis; Tubuh, Sastra dan Budaya Populer. Yogyakarta: Jalasutra.

Selden, Raman. 1994. Panduan Pembaca Teori Sastra Masa Kini. Diterjemahkan oleh Rahmat Djoko Pradopo dan Imran T Abdullah. Yogyakarta: Gama Press. 
Showalter, Elaine. 1989. "Towards a Feminist Poetics" in Contemporary Literary Criticism. Davis, Robert Con (ed.). London: Longman Inc.

Sofia, Adib. 2009. Aplikasi Kritik Sastra Feminis Perempuan dalam Karya-Karya Kuntowijoyo. Yogyakarta: Citra Pustaka.

Sugihastuti \& Itsna Hadi Saptiawan. 2007. Gender \& Inferioritas Perempuan. Yogyakarta: Pustaka Pelajar.

Tong, Rosemarie Putnam. 1998. Feminist Thought. (diterjemahkan oleh Aquarini Priyatna Prabasworo). Yogyakarta: Jalasutra. 